\title{
The Effect Of Early Detection Of Growth and Development Training For Posyandu Caders On Knowledge and Skill Of Motor Stimulation In Darungan Village
}

\author{
Susanti Tria Jaya*, Eva Nur Azizah, Vide Bahtera Dinastiti \\ STIKES Pamenang Kediri, Indonesia \\ *santiandi1401@gmail.com
}

\begin{abstract}
Posyandu activities are limited to screening such as weighing, measuring height, measuring arm circumference, and measuring head circumference. Meanwhile, development monitoring is limited to asking about children's development and adapting to the $\mathrm{MCH}$ handbook. The purpose of this study was to determine the effect of early detection training for posyandu cadres on the knowledge and skills of motor stimulation in Darungan Village, Pare District, Kediri Regency in 2020. This type of research is quasi experiment with one group pretest - posttest design. The research subjects were all of posyandu cadres as many as 30 respondents. The research was conducted from July to September 2020 Darungan Village, Pare District, Kediri Regency. The independent variable is early detection training for posyandu craders, with an interval scale. Dependent Variable, namely Knowledge and Skills About Motor Stimulation. The instruments used were questionnaires and observation sheets, with an interval scale. Statistical analysis using the T- Test on the effect of early detection training on the development of posyandu cadres to knowledge of motor stimulation with a value of $p=0.000$ means at $5 \%$ alpha. This showed that there was an effect of early detection of growth and development training for posyandu caders on knowledge of motor stimulation. The results of statistical tests showed that the value of $\mathrm{p}=0.000$ means that at $5 \%$ alpha. This showed that there was an effect of early detection of growth and development training for posyandu caders on skill of motor stimulation. So that it an increased of $21.33 \%$ and $19,04 \%$. Thus, it is hoped that the stimulation of growth and development in children can be carried out in each posyandu independently and optimally.
\end{abstract}

Keywords : Posyandu Cadres, Early Detection of Growth and Development, Motor Stimulation 


\section{STRADA Jurnal Ilmiah Kesehatan}

DOI: $10.30994 /$ sjik.v9i2.447

ISSN: 2252-3847 (print); 2614-350X (online)

Vol.9 No.2 November 2020 Page.1085-1091

\section{BACKGROUND}

One of the health problems related to growth and development in children under five that can adverse in the short and long term is stunting. Implementable efforts that can prevent stunting runs effectively are monitoring and detecting growth and development. ${ }^{1}$ Early detection of children's growth and development through SDIDTK activities is needed to find early growth deviations, developmental deviations, and mental emotional deviations in children so that intervention and stimulation can be carried out as early as possible to prevent growth irregularities, developmental deviations and sedentary mental emotional deviations. SDIDTK activities are not only carried out on children who are suspected of having problems but must be carried out on all toddlers and preschool children regularly ( 2 times a year). ${ }^{2,3}$ Posyandu as a form of community participation under the Ministry of Health is one of the most basic levels of public health education and monitoring. Monitoring and detection of growth and development in early childhood is part of the duties of posyandu cadres in their respective working areas. Cadre duties are very important and complex because the problem of child development is not only physical growth and development, but also the psychological development of children under five. ${ }^{4}$ Posyandu activities that are usually carried out are limited to screening for childern's growth such as weighing, measuring body height, measuring arm circumference, and measuring head circumference. Meanwhile, development monitoring is limited to asking about children's development and adjust to the MCH handbook. ${ }^{5}$ Lack of training and coaching to improve adequate skills for cadres causes in a lack of understanding of cadres' duties. ${ }^{6}$ Cadres have a close relationship with mothers of toddlers. Delaying of gross motor development in toddlers is the lack of mother's knowledge about motor stimulation. Delaying of gross and fine motor development in toddlers are the lack of early detection of motor stimulation in toddlers. ${ }^{7}$

A preliminary study in July 2019 in Darungan Village, Pare Subdistrict, had 5 posyandu with 30 active cadres. Health problems related to the growth and development of children under five, are 20 children with stunting and 7 chidren with BGM. Based on the description above, the researcher need to conduct research on The Effect Of Early Detection Of Growth And Development Training For Posyandu Caders On Knowledge And Skill Of Motor Stimulation In Darungan Village, which hopefully can give Posyandu cadres the early detection assistance for the growth and development to increase knowledge and skills in motor stimulation in order to prevent enhancement of children under five with stunting or BGM.

\section{METHOD}

This type of research is Quasy Experimental. The research design used was one group pretest - posttest design. The population in this study were all posyandu cadres in the village of Darungan. The sample in this study were all Posyandu cadres in Darungan village, amount to 30 people. The research was conducted in July September 2020. The sampling technique used was Total Sampling. ${ }^{8,9}$ This study consisted of 2 variables, namely the dependent and independent variables. The independent variable is the Posyandu cadre early detection training. Dependent variables are Knowledge and Motor Stimulation skills with an interval scale, which is measured by a questionnaire sheet and an observation sheet

\section{RESULTS}

\section{Table 1}

Characteristics of Respondents Based on Age , Education, Occupation and Parity

Variable $\quad$ F $\%$




\section{STRADA Jurnal Ilmiah Kesehatan}

DOI: $10.30994 /$ sjik.v9i2.447

ISSN: 2252-3847 (print); 2614-350X (online)

Vol.9 No.2 November 2020 Page.1085-1091

\begin{tabular}{lcc}
\hline Age & & \\
31 - 40 years & 13 & 43.33 \\
41 - 50 years & 8 & 26.67 \\
$>$ 50 years & 9 & 30 \\
\hline Education & 7 & 23.33 \\
Junior High & 20 & 66.67 \\
High school & 3 & 10 \\
Bachelor & & \\
\hline Profession & 27 & 90 \\
IRT & 2 & 6.67 \\
entrepreneur & 1 & 3.33 \\
Others & & \\
\hline Parity & 0 & 0 \\
Don't have kids & 7 & 23.33 \\
1 child & 23 & 76.67 \\
$\geq 2$ children & $\mathbf{3 0}$ & $\mathbf{1 0 0}$ \\
\hline Total & & \\
\hline
\end{tabular}

Table 1 showed that, the distribution of respondents mostly in the age of 3140 years $(43,33 \%)$. Most of the respondents have jobs as a housewives (90\%), high school

education background $(66,67 \%)$ and most large respondents have more than two children ( $76,67 \%$ ).

The results showed that there was an effect of early detection training for posyandu cadres on the knowledge and skills of motor stimulation before and after attending the training. This can be seen in tables 2 and 3 .

Table 2

The Effect Of Early Detection Of Growth And Development Training For Posyandu Caders On Knowledge Of Motor Stimulation

\begin{tabular}{cccc}
\hline Knowledge & N & Mean \pm sb & $p$ \\
\hline Knowledge of motor stimulation prior to participating in & 30 & $67.07 \pm 6.275$ & 0,000
\end{tabular}
early detection growth and development training

\begin{tabular}{lll}
\hline Knowledge of motor stimulation after attending early & 30 & $88.40 \pm 7,454$
\end{tabular}

detection detection training for growth and

development training

Table 2 showed that the statistical test value of $p=0.000$, meaning that at $5 \%$ alpha, it can be seen that there was effect of early detection of growth and development training for posyandu caders on knowledge of motor stimulation. 


\section{STRADA Jurnal Ilmiah Kesehatan}

DOI: $10.30994 /$ sjik.v9i2.447

ISSN: 2252-3847 (print); 2614-350X (online)

Vol.9 No.2 November 2020 Page.1085-1091

Table 3

The Effect Of Early Detection Of Growth And Development Training For Posyandu Caders On Skills Of Motor Stimulation.

\begin{tabular}{lcccc}
\hline \multicolumn{1}{c}{ Skills } & $\mathbf{N}$ & Mean $\pm \mathbf{s b}$ & $\boldsymbol{p}$ \\
\hline $\begin{array}{l}\text { Motor stimulation skills prior to attending early detection } \\
\text { of growth and development training }\end{array}$ & 30 & $58.83 \pm 7,042$ & 0,000 \\
\hline $\begin{array}{l}\text { Motor stimulation skills after participating in early } \\
\text { detection growth and development training }\end{array}$ & 30 & $77.87 \pm 5.494$ & \\
\hline
\end{tabular}

Table 3 showed that the statistical test value $p=0.000$, meaning that at $5 \%$ alpha, it can be seen that the effect of early detection of growth and development training for posyandu cadres on skills of motor stimulation.

\section{DISCUSSION}

Thirty respondents who attended training on early detection growth and development, $43.33 \%$ were aged 31-40 years. According to the assumptions of age researchers affecting motor stimulation knowledge and skills , at this age a cadre can easily understand the material presented during training, is very productive in carrying out activities at posyandu such as early detection of growth and development and motor stimulation in children. Based on education, the majority of respondents are high school (66.67\%), educated respondents will have knowledge that affects their behavior. Dimyanti and Mudjiono (2009), Abraham (1991) Inkeles and Smith (1976) (in Suwarno, et al, 2014) argue that education is a strong and consistent predictor of a person's attitudes, values and behavior for the future. ${ }^{10}$ Posyandu cadres education wich is equivalent to high school, it has the potential to bring new ideas and skills in early detection and motor stimulation to children. From the occupation characteristics, it had known that $90 \%$ of posyandu cadres are housewives. According to the assumptions of the researcher, being the respondent's housewife will have sufficient time to do activities at the posyandu because they are not tied to formal work, so that motor stimulation activities for children can be done more optimally. The parity of respondents is mostly $76,67 \%$ are having children $\geq 2$, of course the more children make posyandu cadres more understanding and have personal experiences about growth and development and motor stimulation in children

\section{The Effect Of Early Detection Of Growth And Development Training For Posyandu Caders On Knowledge Of Motor Stimulation}

Referring of the results, it can be seen that there was an increase in knowledge of the posyandu cadres before and after training on early detection of growth and development. Training on early detection of child development anf development was carried out using modules created by the research team based on Guidelines for the Implementation of Early Detection Stimulation and Growth and Development Intervention in 2016. Before the training on early detection of growth and development, the mean level of knowledge posyandu cadrs about children's motor stimulation was $67,07 \%$. After training on early detection of growth and development was carried out, there was an increase in the mean level of posyandu cadres knowledge of children's motoric stimulation by $88,40 \%$. This happened because posyandu cadres have often been exposed to information about children's health from the local puskesmas. According Indrayani, Diyan (2019) knowledge is obtained on facts, information, and skills that acquired form experience or education and 


\section{STRADA Jurnal Ilmiah Kesehatan}

DOI: $10.30994 /$ sjik.v9i2.447

ISSN: 2252-3847 (print); 2614-350X (online)

Vol.9 No.2 November 2020 Page.1085-1091

understanding of the problem or phenomena and parenting is multidimensional. ${ }^{11}$ According Notoatmo jo, 2007 ( in Fanny's research, 2018) regarding the empowerment of health in early detection of stunting and stimulation of growth and development in toddler, information obtained from various sources will affect a person's level of knowledge, so that if someone gets a lot of information, that person will tend to have broader knowledge. ${ }^{12}$

The results of statistical tests the effect of early detection of growth and development training for posyandu caders on knowledge of motor stimulation showed that the value of $\mathrm{p}=0.000$ means that at $5 \%$ alpha. This showed that there was an effect of early detection training for posyandu cadres growth and development on posyandu cadres knowledge of motor stimulation. The early detection training activities for posyandu cadres is not only by used lectures, but also with discussions, simulations and practicum that supported the achievement of the expected learning objectives. In this activity posyandu cadres also demonstrated how to perform gross and fine motor stimulation in children. Asyaroh's research (2017) state that the level of knowledge of the cadres from the pre-test and posttest results increased by $1,45 \%$ after being given intervention with complementary breastfeeding demonstration method. ${ }^{13}$ Posyandu cadres knowledge can be obtained from the facts, information, and skills a person gets through experience, education and understanding of a problem and the activities of cadres during the counseling that come face to face with toddlers continuously. To respond the various needs of children's growth and development, posyandu cadres must be able to develop knowledge, start from basic knowledge or principles of child development and norms that help mothers under five to maintain their child's growth and development according to their age and do gross motor and fine motor stimulation to child. Posyandu cadres who are close to mother toddlers must know more about the process of child growthvand development as well as factors that affect the process of child growth and development.

\section{The Effect Of Early Detection Of Growth And Development Training For Posyandu Caders On Skills Of Motor Stimulation.}

The assessment of posyandu cadres skills regarding motor stimulation in children was carried out using a developmental prescreening questionnaire (KPSP) and also gross and fine motor stimulation interventions for children according to the child's age. Prior to the training on early detection of growth and development, the average skill level of posyandu cadres regarding children's motor stimulation by $58,83 \%$. After training on early detection of growth and development, there was an increase in the mean level of skill posyandu cadres regarding children's motor stimulation by $77,87 \%$. This happened because posyandu caders have often been exposed to information about children's health from the local puskesmas. The results statistical test on the effect of early detection training for posyandu caders on the skills of motor stimulation showed that the value of $p$ $=0.000$ means at $5 \%$ alpha. This showed that there was an effect of early detection training for posyandu cadres on the skills of posyandu cadres regarding motor stimulation. Posyandu cadres practices or skills regarding motor stimulation in children related to knowledge and attitudes, and often involved the application of acquired knowledge. According to Gadsden's modified theory, 2016 (in Indrayani, 2019) stated that a person's attitude often determines whether she will use knowledge and turn it into practice. ${ }^{11}$

The implementation of motor stimulation skills by posyandu cadres must have a basis, namely information and training. Skills development started from what a posyandu cadre has mastered, and what skills she has not mastered yet. This suggested that early 


\section{STRADA Jurnal Ilmiah Kesehatan}

DOI: $10.30994 /$ sjik.v9i2.447

ISSN: 2252-3847 (print); 2614-350X (online)

Vol.9 No.2 November 2020 Page.1085-1091

detection training for growth and development becomes more effective in improving motor stimulation skills for children. The process of developing motor stimulation skills in children can be carried out after learning activities for early detection of growth and development, follow-up and development of knowledge that can be seen from the ability of posyandu cadres to apply them motor stimulation skills for children in age 0-6 years old. If the posyandu cadres do not have the knowledge, then the posyandu cadres lack of good skill in stimulating children's motor development.

Knowledge and skills of posyandu cadres about stimulation of growth and development are very important to improve the quality of children in the posyandu area . The active role of posyandu cadres in helping the community to do early detection of growth and development and motor stimulation in children and in collaboration with the puskesmas and related agencies to carry out reporting can contribute to the realization of an increase in the degree of community health, especially in children with stunting or at risk of stunting, children with the risk of growth and developmental disorders can be detected immediately and get treatment quickly and precisely so that to help prevent or minimize adverse effects on children and families and reduce morbidity in the region. In this study, there was an effect of early detection development training on the knowledge and skills of mothers about stimulating growth and development in children with an increase of $21,33 \%$ and $19,04 \%$. Thus, it is hoped that the stimulation of growth and development in children can be carried out in each posyandu independently and optimally

\section{CONCLUSSION}

Based on the results of the study, it can be concluded that the training method for early detection of growth and development has a very significant effect on the knowledge and skills of mothers about stimulating growth and development of posyandu cadres. This is due to their use of various strategies in teaching method to increase the understanding of posyandu cadres to stimulate motor development of children aged 0-6 years.

\section{ACKNOWLEDGMENTS}

The authors wish to thank to Direktorat Riset dan Pengabdian Masyarakat (DRPM) Kemenristekdikti 2020 with research contract No. 131/SP2H/ LT-MONO/LL7/2020. The authors also wish to thanks Puskesmas Bendob and Darungan Village, Pare District, Kediri Regency

\section{REFERENCES}

1. Adistie, Lumbantobing, Maryam. 2018. Pemberdayaan Kader Kesehatan Dalam Deteksi Dini Stunting dan Stimulasi Tumbuh Kembang pada Balita.http://jurnal.unpad.ac.id/mkk/article/download/18863/9099.

2. Oktarina, \& Mugeni. (2015). The Relationships Among Knowledge, Attitude, and Compliance of Gravida (Expectant Mothers) and the Utilization of Maternal and Child Health $(\mathrm{MCH})$ Book at Puskesmas Geger and Kedundung in Bangkalan, East Java, Year 2013. Buletin Penelitian Sistem Kesehatan, 18(2), 141-150.

3. Kemenkes RI. 2016. Pedoman Pelaksanaan Stimulasi, Deteksi dan Intervensi Dini Tumbuh Kembang Anak. Kementerian Kesehatan RI

4. Sianturi, Tambunan, Ningsih. 2013. Peningkatan Kemampuan Kader Kesehatan Dalam Melakukan Deteksi Tumbuh Kembang Balita Melalui Pelatihan. http:// www. ejurnal.poltekkesjakarta.ac.id. 


\section{STRADA Jurnal Ilmiah Kesehatan}

DOI: $10.30994 /$ sjik.v9i2.447

ISSN: 2252-3847 (print); 2614-350X (online)

Vol.9 No.2 November 2020 Page.1085-1091

5. Putriningtyas, Sutarni. 2016. Pengaruh Pelatihan Deteksi Dini Tumbuh Kembang Balita (DTKB) Terhadap Motivasi Dan Ketrampilan Kader Di Dusun Soragan Ngestiharjo Kasihan Bantul. Program Studi Bidan Pendidik Jenjang Diploma IV. Fakultas Ilmu Kesehatan Universitas 'Aisyiyah Yogyakarta

6. Zainiah,N. 2014. Hubungan Frekuensi Pelatihan Yang Diikuti Kader Dengan Tingkat Ketrampilan Kader Dalam Pelayanan Posyandu Balita Di Desa Nogotirto Gamping Sleman Yogyakarta dalam http:// www.opac.say.id

7. Singla, D. R., Kumbakumba, E., \& Aboud, F. E. 2015. Effects of a parenting intervention to address maternal psychological wellbeing andchild development and growth in rural Uganda: A community-based, cluster-randomised trial. The Lancet Global Health, 3(8), e458-e469. https://doi.org/10.1016/S221409X(15)00099-6

8. Sugiyono. 2012. Metode Penelitian Kuantitatif, Kualitatif, dan R\&D. Bandung: Alfabeta

9. Hidayat, AAA. 2014. Metode Penelitian Kebidanan dan Teknik Analisis Data. Jakarta: Salemba Medika

10. Suwarno, J. Sartohadi, Sunarto, dan D. Sudharta. 2014. Kajian Pengaruh Tingkat Pendidikan Terhadap Perilaku Masyarakat dalam Pengelolaan Lahan Rawan Longsor Lahan Di Kecamatan Pekuncen Kabupaten Banyumas. Geoedukasi Volume III Nomor 1, Maret 2014. https://media.neliti.com/media/publications/55758-ID-kajian-pengaruhtingkat-pendidikan-terha.pdf

11. Indrayani, D., Legiati, T., Hidayanti, D. 2019. Kelas Ibu Balita Meningkatkan Pengetahuan dan Keterampilan Ibu dalam Stimulasi Tumbuh Kembang. Jurnal Kesehatan Prima, Volume 13 No. 2, Agustus 2019. http://jkp.poltekkesmataram.ac.id/index.php/home/article/view/240

12. Adistie,F., Lumbantobing, VBM., Maryam, NNA. 2018. Pemberdayaan Kader Kesehatan Dalam Deteksi Dini Stunting dan Stimulasi Tumbuh Kembang pada Balita. Media Karya Kesehatan. http://jurnal.unpad.ac.id/mkk/article/view/18863

13. Aisyaroh,N., Susiloningtyas, Is, Mubarok.2017. Pengembangan Intervensi MP-ASI Dengan Metode Demonstrasi Pada Kader Posyandu Di Desa Batur Kecamatan Getasan Kabupaten https://jurnal.unimus.ac.id/index.php/psn12012010/article/view/2352 